\title{
Phenomenologizing Filipino Organic Thought: Florentino H. Hornedo's Philosophical Anthropology
}

Fleurdeliz R. Altez-Albela

\begin{abstract}
The aim of this paper is to show how Florentino $\mathrm{H}$. Hornedo's intellectual life is a consistent articulation of a philosophy of man and human existence bolstered by interdisciplinarity. The approach of this study will be hermeneutic, as it will present a reading of the book The Power to Be: A Phenomenology of Freedom and selected essays in the anthologies Pagpapakatao, Christian Education: Becoming Person-for-Others and Pagmamahal at Pagmumura and Other Essays. These texts are read in the context of his story, which shall eventually give what he precisely means by phenomenology, thereby justifying the use of what he calls "organic thinking" as a method in doing philosophy of the human person.
\end{abstract}

Keywords: Hornedo, Filipino philosophy, philosophical anthropology, human person

\section{Hornedo's Humanism}

7 he passing of Florentino H. Hornedo last 9 December 2015 was a tremendous loss to the Filipino academe. In these times when Philippine education is facing a great leap because of the interdisciplinary and dialogic demands of the K12 program, the academia could not truly afford the cost of being left by intellectuals who are capable of articulating knowledges in different fields while not losing in touch with

(c) 2016 Fleurdeliz R. Altez-Albela

http://www.kritike.org/journal/issue 19/altez-albela december2016.pdf ISSN 1908-7330

(c) BY-NC-ND 


\section{HORNEDO'S PHILOSOPHICAL ANTHROPOLOGY}

the idea that the fundamental goal of learning is to humanize. In such critical times, we could not lose a Filipino who is known to be a pioneer in cultural and Ivatan studies, moreso a sturdy pillar in education, history, philosophy and literature. We are in dire need of seasoned teachers who are by themselves Renaissance people and can blaringly remind us that focused and intense study is nothing if it would make us forget that we are humans; and how teaching becomes parroting if the student would not be dared to venture into new horizons, even if it would mean going beyond his field of concentration.

Deep interest in biology and animals might have brought the young Florentino to natural science. But because of poverty, "fear of breaking laboratory equipment," and his love for learning, he decided to pursue a college degree in Education. Afterwhich was a life-story of an engagement with the different human sciences, or as how Pada describes, "an entanglement with a caboodle of disciplines in humanities," that is oftentimes locally contextualized - "traversing all walks of life towards the understanding of humanity and its persistence to live life in the most meaningful sense." 1 The first fundamental reference to Hornedo's philosophical insight is the Master's thesis he wrote and almost circulated in 1972. The work, which he said was pretentiously entitled by its editor as The Philosophy of Freedom, was withdrawn from circulation as it has "disturbed people seriously enough." 2 In 2000, the UST Press picked up and republished the book with the title The Power to Be: A Phenomenology of Freedom.

In this work, he claimed to have entertained the basic human questions that he discovered after years of teaching many subjects in the Humanities. More particularly, he invited his readers to reflect on the "main stuff" of freedom given its logical and metaphysical premises. After going through numerous classical and contemporary literary and philosophical theories on being and human becoming, Hornedo argued that freedom is a power, strength or a kind of "autonomous energy" which makes action possible and thereby fostering development and justice. But as Hornedo also claimed to have done a sort of "phenomenology," the method of the book

${ }^{1}$ Roland Theuas DS. Pada, "The Humanity of Florentino Hornedo in the Humanities," in Kritike, 9:2 (2015), 1-2.

${ }^{2}$ Florentino Horned, Preface to the New Edition of The Power to Be: A Phenomenology of Freedom (Manila: UST Publishing House, 2000), ix.

(C) 2016 Fleurdeliz R. Altez-Albela

http://www.kritike.org/journal/issue 19/altez-albela december2016.pdf

ISSN 1908-7330

(c) BY-NC-ND 
baffled some readers. With the demand for a more intense demonstration of Hornedo's familiarity with phenomenology as a "theoretical framework," his forceful concentration in keeping phenomenology as a "method" and his novel take on human nature as free and powerful remained at the helm.

\section{The Weaving of a Corporeal and Localized Philosophical Anthropology}

What followed after The Power to Be are publications that are more straightforward in doing phenomenology (still as a method) and in speaking about human nature. Noticeable are his more straightforward expositions of phenomenological theories, while not losing his habit of citing examples coming from his different fields of studies.

Most notable of which is his essay Pagpapakatao, where he used the concepts of Edmund Husserl in demonstrating how modernist dualisms are connected in the field of human, corporeal experience. In this essay, he echoed in the vernacular about how Husserl thinks of consciousness (kamalayan bilang kaalaman, paglalaman) as "consciousness of," and have shown how a local articulation of such noetic act can best depict the relation between noesis which he described malay-tao and its content which he translated into laman ng malay-tao. With the use of Filipino, he regarded consciousness as malay-tao to be able to link the mind to the world through experience with the agency of the body (katawan). And so, this renders an immediate connection to the self-exclamation, Ako ang aking katawan! ("I am my body!")

The phenomenological claim above, most likely, is not just derived from Husserl. It is something that he has been declaring in some of his earlier works, specifically in Catholic Education: Growing to Become Men/Women for Others (1988). ${ }^{3}$ In this work, he writes:

As embodied being, he is as well and has a body. $\mathrm{He}$ identifies with his body, but at the same time regards his identity as not co-terminus with his body. He is at once a body and more than a body. He is able to transcend

\footnotetext{
${ }^{3}$ Cf. Florentino Hornedo, "Catholic Education: Growing to Become Men/Women for Others," in Unitas 61:3 (1988), 633-646. See also Florentino Hornedo, Christian Education: Becoming Person-for-Others: Essays in Philosophy of Education (Manila: UST Publishing House, 1995).

(C) 2016 Fleurdeliz R. Altez-Albela http://www.kritike.org/journal/issue 19/altez-albela december2016.pdf ISSN 1908-7330
} 


\section{HORNEDO'S PHILOSOPHICAL ANTHROPOLOGY}

being merely body, or merely being product of physical forces. He is temporal, and therefore subject to time. He is born and grows old and wears away. But in the time of his passage, he creates manifestation of his passage through time. He builds ideas and institutions. He embodies his ideas, that is he gives them concrete reality, and in so doing he creates history. ${ }^{4}$

From this point, Hornedo departs from Husserl and shifts to a more embodied elaboration of how it is to be human. With a consciousness that is corporeally connected to the world, he proceeds to explain how man weaves his own story in time through creative acts, work, freedom, love and justice. These are the ways by which we thrive in time - leave our historical imprints. Creativity testifies how the Self is a decisive and meaningful product - a beautiful work of existence. In work, we proclaim our value (pinapahayag ang sariling pakinabang), through what we do and what we can offer. Through creativity and work, one's interiority or subjectivity is revealed, which Hornedo called kalooban. He elaborated on this by using Cuvar's anthropological metaphor of the palayok. For Hornedo, such self-making is an expression of strength that is freedom, and further strength does not only yield change within the Self but also the capacity to pass on to others such power. Ang pagpapalaya ay pagbibigay lakas, pagbibigay kakayahan ("To set free is to empower, to grant capabilities").

Man spreads his freedom, his human-ness, by being a man for others. "The inquiry into the wholeness of himself changes the meaning of the world around him by relating them to him not as things or objects but as meaning. He discovers that meaning is not objectivity but relatedness. And that relatedness does not happen simply as a given, but that it is a project of his freedom." ${ }^{5}$ Inasmuch as one is born, or better yet, thrown into a society, Hornedo upholds that human freedom poses the challenge to respond and participate with the projects of Others. Such "ethical" or "social" demand is best seen by understanding that rights which mirror our human worth can only be granted in the presence of others who would dutifully recognize our value as persons and address what we deserve.

${ }^{4}$ Ibid., 31.

${ }^{5}$ Ibid., 32.

(C) 2016 Fleurdeliz R. Altez-Albela

http://www.kritike.org/journal/issue 19/altez-albela december2016.pdf

ISSN 1908-7330

(cc) EY-NC-ND 
Higit sa regalo, karapatan ay kaloob ng lipunan - malayang ibinibigay ng ayon sa halaga ng tao, para sa kanyang pagtubo. Samantala, tao ring tumatanggap ang siyang nagbibigay ng kairalan ng pag-unlad. ${ }^{6}$

(More than a gift, rights are offered by the society, as freely bestowed in accordance to human worth and progress. Meanwhile, it is also humane to grant opportunities for, and participate in projects of becoming)

The above quotation highlights the anthropological basis of society and progress. For Hornedo, society and even the force of freedom demands each Self to be responsible, to participate, and to share: ang managot, makisangkot, ang gamitin ang lakas ng pandama para tumugon sa masidhing pangangailangan $i b a$ ("to respond, be involved and use one's sensibilities to address difficult needs").

For Hornedo, the pinnacle of sociality is love, an act that advances in the field of human values. He regarded this utmost expression of the utmost human value as pagmamahal, coming from the root mahal (which means either "valuable" or "expensive") and of which one pays for the highest price. The opposite of which is pagmumura, which is the Filipino term for defamation. Now, this love is offered in the midst of justice, through the arbitration of laws and institutions. But despite the seeming stifles, Hornedo quips that the highest of laws is granted by God's commandment to love.

What seals the phenomenological deal is with Hornedo's echoing of the existential (Heideggerian) claim that man is a Being-toward-death. This speaks not just of man's final stamp of meaning, but also how the body concedes to the passing of time which gears one to find the Infinite, God.

This accents the experience of man of the seeking after that which cannot be dissolved either by the passage of time or of death, the concern for the Absolute. ${ }^{7}$

\footnotetext{
${ }^{6}$ Ibid.

${ }^{7}$ Ibid.
} http://www.kritike.org/journal/issue 19/altez-albela december2016.pdf 


\section{6}

HORNEDO'S PHILOSOPHICAL ANTHROPOLOGY

For Hornedo, death is a corporeal closure that conditions man to anxiously value his freedom. But more importantly, it orients man toward a necessary dimension he has to look forward to, and that is the dwelling in the Absolute.

\section{By Way of Conclusion: Phenomenology as Freedom from Intellectual Necrophilia}

In his preface to The Power to Be, Hornedo mentions that man is bound to engaged with two conflicting schools of thought: fundamentalism and postmodernism. For him, both positions evade personal decision and commitment to a rational and critical engagement with the search for a ground for being and action. Fundamentalism and postmodernism deprive man of his self-governance and the power to be-for-others. For Hornedo, there is a need to redirect the inquiry of freedom, from the dialectics of theories towards the most authentic and self-scrutinizing ways.

Hornedo's turn to phenomenology could be described as a shift to organic thought, articulating the relationship between thought and the act of living. He can be remembered in many lectures complaining about philosophy's obsession with death - a training in necrophilia that leads to mummification and parroting of concepts that will only be repeated by the next batch of scholars. All of these, we celebrate while in truth, we have not truly escaped from that same old shell.

Consistent with his inquiry on human freedom, Hornedo's intellectual excursus, regardless of what his critics say, have clearly liberated the local philosophical inquiry from just flipping through pages. His courageous employment of phenomenology as a method have prompted his students and followers to put philosophies in dialogue with other human sciences, both in writing and in deeds. Doing so will always be a difficult task because venturing in other fields would mean a demand to refocus and to courageously leap out of our theoretical and textual comfort zones. For some, it would even require immersion in the archives or fieldwork. But for all that it is worth, we all believe nothing shall be wasted. Because as we were taught how to have thoughts that reflect our ways, our lives; we experience freedom and we empower previously cloistered thoughts.

(C) 2016 Fleurdeliz R. Altez-Albela

http://www.kritike.org/journal/issue 19/altez-albela december2016.pdf

ISSN 1908-7330

(c) BY-NC-ND 
Department of Philosophy, University of Santo Tomas, Philippines

\section{References}

Hornedo, Florentino, "Catholic Education: Growing to Become Men/Women for Others," in Unitas, 61:3 (1988).

Christian Education: Becoming Person-for-Others: Essays in Philosophy of Education (Manila: UST Publishing House, 1995).

The Power to Be: A Phenomenology of Freedom (Manila: UST Publishing House, 2000).

Pada, Roland Theuas DS., "The Humanity of Florentino Hornedo in the Humanities," in Kritike, 9:2 (2015). 